\title{
Neopterin Serum sebagai Prediktor Dini Luaran Perburukan pada Sepsis Neonatorum
}

\author{
Ahmad Hafidz, Tetty Yuniati, Purboyo Solek \\ Departemen Ilmu Kesehatan Anak, Fakultas Kedokteran, \\ Universitas Padjadjaran/RSUP Dr. Hasan Sadikin, Bandung, Indonesia
}

\begin{abstract}
Abstrak
Neopterin telah diketahui sebagai biomarker untuk diagnostik sepsis neonatorum awitan dini. Hingga saat ini belum diketahui peran neopterin sebagai biomarker untuk memprediksi luaran sepsis neonatorum awitan dini maupun awitan lanjut. Tujuan penelitian ini menentukan neopterin serum sebagai biomarker prediktor sepsis neonatorum awitan dini dan lanjut. Penelitian dilakukan pada bulan Mei-Juli 2017 di RSUP Dr. Hasan Sadikin Bandung. Seluruh neonatus yang memenuhi kriteria sepsis neonatorum, yaitu didapatkan skor Tollner $\geq 10$, dilakukan pemeriksaan neopterin serum menggunakan metode ELISA. Subjek kemudian diikuti dan dikelompokkan menjadi luaran perbaikan dan perburukan. Analisis menggunakan receiver operating characteristic (ROC) untuk mendapatkan luas area under curve, menentukan titik potong serta sensitivitas dan spesifisitas. Subjek penelitian terdiri atas 42 neonatus, mayoritas karakteristik neonatus yang mengalami luaran perburukan berjenis kelamin laki-laki (10 subjek), sepsis awitan dini (11 subjek), cara persalinan dengan operasi (11 subjek), dan tempat persalinan di RS (14 subjek). Temuan kadar neopterin pada luaran perburukan lebih tinggi dibanding dengan luaran perbaikan dan disimpulkan terdapat perbedaan yang bermakna $(\mathrm{p}<0,01)$. Kadar neopterin rata-rata yang didapatkan pada sepsis luaran perburukan 60,97 $\mathrm{ng} / \mathrm{mL}$ dengan rentang kadar 40,63-92,04 ng/mL. Luas area di bawah kurva ROC kadar neopterin adalah 0,981 (95\% $\mathrm{IK}=0,882-1,000 ; \mathrm{p}<0,001)$. Kadar titik potong neopterin $>43,13$ dengan sensitivitas $94,1 \%$ dan spesifisitas $96,0 \%$. Simpulan, kadar titik potong neopterin adalah 43,13 ng/mL serta memiliki sensitivitas 94,1\% dan spesifisitas 96,0\%. Biomarker ini dapat menjadi salah satu parameter dalam memprediksi dini luaran perburukan sepsis neonatorum awitan dini dan awitan lanjut.
\end{abstract}

Kata kunci: Luaran, neopterin, sepsis neonatorum

\section{Neopterin Serum as Early Predictor of Poor Outcome in Neonatal Sepsis}

\begin{abstract}
Neopterin was known as the biomarker for diagnosed early onset neonatal sepsis. Nowadays it has been proven for neopterin as predictors of poor outcome in early and late neonatal sepsis. The objective of this study was to determine serum levels of neopterin as predictors of poor outcome in early and late neonatal sepsis. The study held from May to July 2017 in Dr. Hasan Sadikin General Hospital Bandung. All subjects were neonatal sepsis with Tollner score $\geq 10$ observed for serum levels of neopterin with ELISA method and then followed during hospitalization. The outcome defined as good and poor outcomes. The data were analyzed using receiver operating characteristic (ROC) for getting area under curved, cut-off point and also sensitivity, specificity. Research subjects consisted of 42 neonates, the majority which experienced poor outcomes were male (10 subjects), early onset sepsis (11 subjects), section cesarean procedure (11 subjects) and were born in a hospital (14 subjects). Serum neopterin levels findings significantly correlated with poor outcomes. Mean of poor outcomes in sepsis was $60.97 \mathrm{ng} / \mathrm{mL}$ with observed levels 40.63-92.04 ng/mL. Area under the ROC curve of neopterin were 0.981 (95\% CI=0.882-1.000; $\mathrm{p}<0.001$ ). Cut off levels of neopterin $>43.13$ with sensitivity $94.1 \%$ and specificity $96.0 \%$. In conclusion, cut off levels of neopterin $>43.13$ with sensitivity $94.1 \%$ and specificity $96.0 \%$. Neopterin defined as a biomarker for the early predictor of poor outcome in early and late onset neonatal sepsis.
\end{abstract}

Key words: Neonatal sepsis, neopterin, outcome

Received: 4 October 2017; Revised: 18 December 2017; Accepted: 24 December 2017; Published: 27 December 2017

Korespondensi: Ahmad Hafidz, dr. Departemen Ilmu Kesehatan Anak, Fakultas Kedokteran, Universitas Padjadjaran/RSUP Dr. Hasan Sadikin. Jln. Pasteur No. 38, Bandung 40163, Jawa Barat, Indonesia. Telepon: (022) 2034953/55. HP: 081223800054. E-mail: abuahmadhafidz@gmail.com 


\section{Pendahuluan}

Sepsis neonatorum adalah sindrom klinik akibat respons sistemik terhadap infeksi pada bulan pertama dari kehidupan bayi., ${ }^{1,2}$ Insidensi sepsis neonatorum bakterial awitan dini di negara maju berkisar 1 kasus sampai 4 kasus tiap 1.000 kelahiran hidup. Insidensi di negara berkembang lebih tinggi $5^{-8}$ kali lipat, dengan angka yang pernah dilaporkan berkisar 20-37 kasus tiap 1.000 kelahiran hidup. ${ }^{3}$ Insidensi neonatal sepsis yang tinggi berhubungan dengan morbiditas dan mortalitasnya yang juga tinggi. Bayi matur maupun bayi prematur apabila terkena infeksi mempunyai risiko sebesar 30-80\% untuk terjadi gangguan neurodevelopmental dan 30-100\% berpeluang terjadi gangguan perkembangan otak. ${ }^{4-6}$

Penelitian mengenai neopterin dilaksanakan di Mesir membuat simpulan neopterin biomarker bermanfaat untuk dapat memprediksi angka kematian pada sepsis awitan dini pada neonatus. ${ }^{7}$ Penelitian lain juga mengonfirmasi neopterin mempunyai korelasi yang signifikan dengan tingkat mortalitas pada suatu sepsis neonatorum sehingga hal ini merupakan faktor diagnostik dan prognostik yang baik untuk sepsis neonatorum awitan dini. ${ }^{8}$ Penelitian yang dilaksanakan di Bandung sebelumnya juga sudah membuktikan neopterin merupakan perangkat diagnosis sepsis neonatorum yang baik pada bayi kurang bulan. ${ }^{9}$

Penelitian ini mempunyai tujuan menentukan kadar neopterin serum sebagai prediktor dini perburukan luaran pada sepsis awitan dini dan awitan lanjut pada neonatus.

\section{Metode}

Penelitian dilakukan pada bulan Mei-Juli 2017. Kriteria inklusi penelitian, yaitu semua neonatus yang memenuhi kriteria sepsis neonatorum didapatkan skor Tollner $\geq 10$. Kriteria eksklusi adalah neonatus dengan kelainan kongenital mayor. Subjek penelitian ini dilakukan dengan cara consecutive sampling, kemudian subjek penelitian dicatat karakteristiknya meliputi jenis kelamin, berat badan lahir, cara persalinan, onset sepsis, tempat persalinan, dilakukan pemeriksaan parameter laboratorium serta kadar neopterin serum, dan diikuti hingga kondisi perbaikan klinis atau perburukan.

Pemeriksaan kadar neopterin serum dilakukan di Laboratorium RSUP Dr. Hasan Sadikin. Darah diambil $2 \mathrm{~mL}$ dimasukkan ke dalam tabung yang berisi ethylenediaminetetraacetic acid (EDTA), disentrifugasi, selanjutnya diambil $1 \mathrm{~mL}$ serum diperiksa menggunakan metode ELISA.

Perbaikan klinis ditentukan bila gejala klinis sepsis menunjukkan perbaikan dan pemeriksaan laboratorium: hemoglobin, leukosit, trombosit, dan CRP mempunyai nilai normal. Perburukan klinis ditentukan bila gejala klinis sepsis masih didapatkan dan pada pemeriksaan laboratorium: hemoglobin, leukosit, trombosit, dan juga CRP mempunyai nilai tidak normal.

Karakteristik pada kedua kelompok penelitian, yaitu perburukan dan perbaikan diuji dengan cara menggunakan uji chi-kuadrat atau Fisher exact untuk data kategoris dan untuk perbedaan kadar neopterin menggunakan uji t independen. Sesudah itu, dilanjutkan dengan menggunakan analisis kurva receiver operating characteristic (ROC) digunakan untuk mendapatkan luas area under curve (AUC) yang menentukan titik potong serta sensitivitas dan spesifisitas. Semua analisis diolah dengan software SPSS untuk windows versi 17 .

Penelitian ini sudah disetujui oleh Komisi Etik dan Penelitian Kesehatan RSUP Dr. Hasan Sadikin Bandung melalui surat Nomor: LB.04.01/ A05/EC/195/VII/2017 dan persetujuan orangtua yang tertulis diperoleh (informed consent).

\section{Hasil}

Sepsis neonatorum berjenis kelamin laki-laki lebih banyak daripada perempuan, kejadian sepsis awitan dini lebih banyak ditemukan dibanding dengan sepsis awitan lanjut. Berat badan lahir didominasi neonatus dengan berat badan $>1.500$ gram. Persalinan secara operasi lebih banyak dibanding dengan cara persalinan per vaginam. Beberapa faktor risiko terhadap bayi maupun ibu akan mengakibatkan luaran bayi dengan sepsis neonatorum. Berdasar atas pemeriksaan kultur darah didapatkan positif hanya pada 4 subjek, masing-masing 2 subjek pada kelompok luaran perburukan dan perbaikan, dengan jenis kuman $S$. hemolyticus, $S$. aureus, $S$. hominis, dan Klebsiella pneumoniae. Karakteristik umum subjek penelitian ditampilkan pada Tabel 1 .

Karakteristik pada neonatus dan maternal dibandingkan dengan luarannya dikelompokkan menjadi luaran perbaikan dan luaran perburukan seperti yang telah terangkum pada Tabel 2 . Perbandingan luaran perbaikan dan perburukan 
Tabel 1 Karakteristik Umum Penelitian

\begin{tabular}{|c|c|c|}
\hline & \multicolumn{2}{|c|}{ Subjek Penelitian } \\
\hline & $n=42$ & $\%$ \\
\hline $\begin{array}{l}\text { Jenis kelamin } \\
\text { Laki-laki } \\
\text { Perempuan }\end{array}$ & $\begin{array}{l}26 \\
16\end{array}$ & $\begin{array}{l}62 \\
38\end{array}$ \\
\hline $\begin{array}{l}\text { Berat badan lahir }(\mathrm{g}) \\
\quad \leq 1.500 \\
\quad>1.500\end{array}$ & $\begin{array}{l}15 \\
27\end{array}$ & $\begin{array}{l}36 \\
64\end{array}$ \\
\hline $\begin{array}{l}\text { Cara persalinan } \\
\text { Per vaginam } \\
\text { Operasi }\end{array}$ & $\begin{array}{l}13 \\
29\end{array}$ & $\begin{array}{l}31 \\
69\end{array}$ \\
\hline $\begin{array}{l}\text { Onset sepsis (hari) } \\
\quad>3 \\
\leq 3\end{array}$ & $\begin{array}{l}16 \\
26\end{array}$ & $\begin{array}{l}38 \\
62\end{array}$ \\
\hline $\begin{array}{l}\text { Tempat persalinan } \\
\text { Luar rumah sakit } \\
\text { Rumah sakit }\end{array}$ & $\begin{array}{l}12 \\
30\end{array}$ & $\begin{array}{l}29 \\
71\end{array}$ \\
\hline $\begin{array}{l}\text { Kultur darah } \\
\text { Positif } \\
\text { Negatif }\end{array}$ & $\begin{array}{c}4 \\
38\end{array}$ & $\begin{array}{c}9 \\
91\end{array}$ \\
\hline $\begin{array}{l}\text { Faktor risiko } \\
\text { Ada } \\
\text { Tidak ada } \\
\end{array}$ & $\begin{array}{c}36 \\
6 \\
\end{array}$ & $\begin{array}{l}86 \\
14 \\
\end{array}$ \\
\hline
\end{tabular}

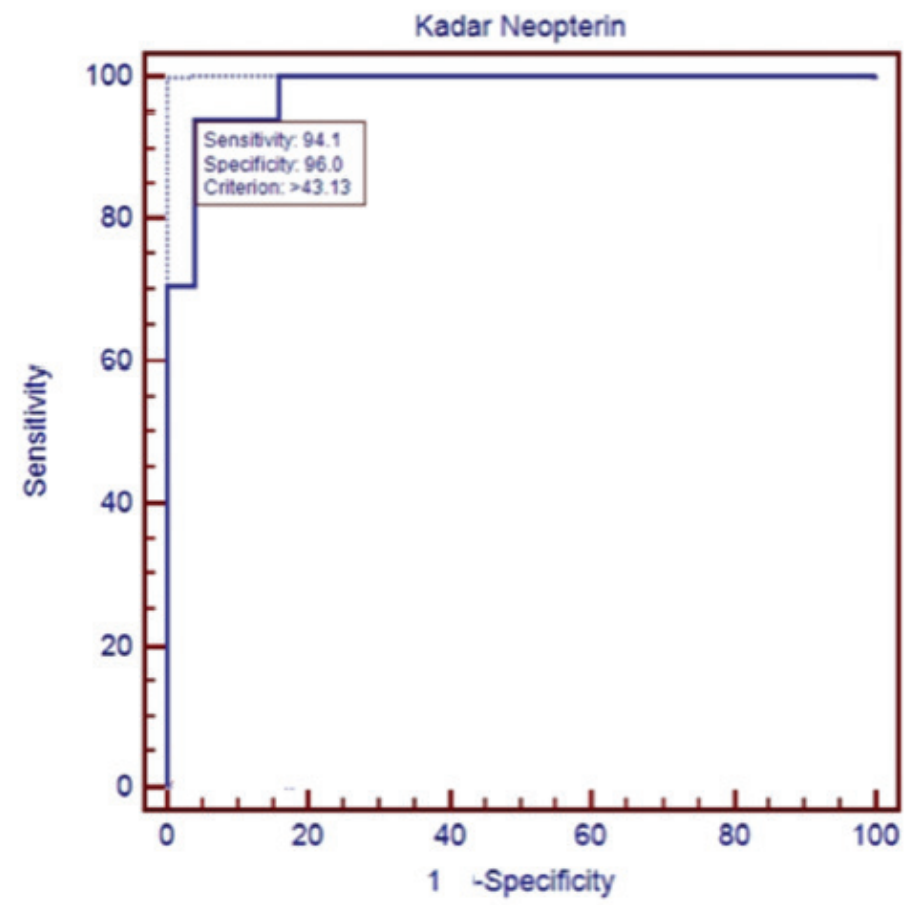

Gambar Kurva ROC Kadar Neopterin Serum sebagai
Indikator Luaran Perburukan 


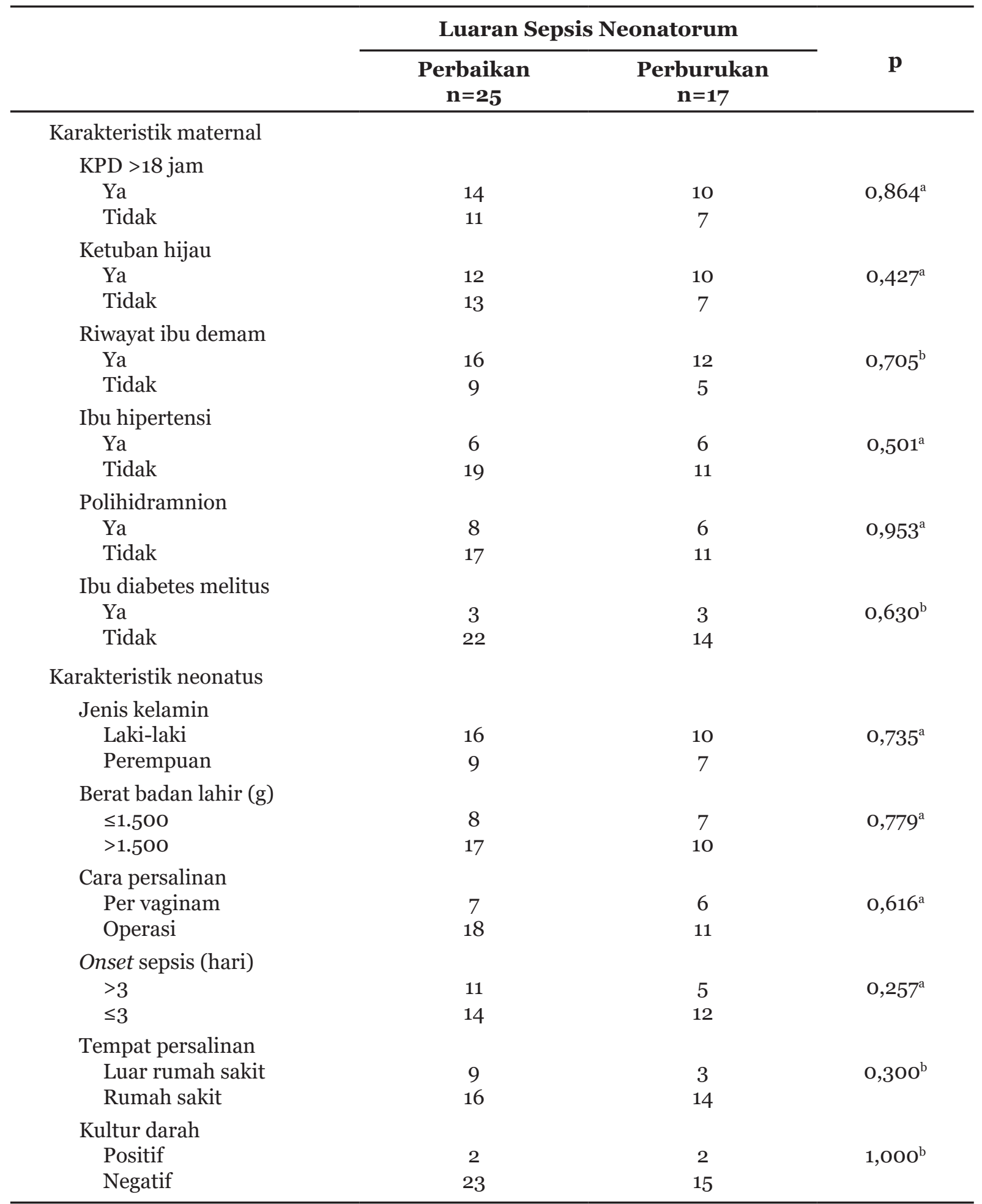

Keterangan: n=frekuensi, aji chi-kuadrat, buji Fisher exact 
Tabel 3 Perbandingan Kadar Neopterin Serum dengan Luaran Sepsis Neonatorum

\begin{tabular}{lccc}
\hline & \multicolumn{2}{c}{ Luaran Sepsis Neonatorum } & \\
\cline { 2 - 3 } Kadar Neopterin Serum & $\begin{array}{c}\text { Perbaikan } \\
\mathbf{n = 2 5}\end{array}$ & $\begin{array}{c}\text { Perburukan/ } \\
\text { Meninggal } \\
\mathbf{n = 1 7}\end{array}$ & $\mathbf{p}$ \\
\hline Rata-rata (SD) & $35,76(4,43)$ & $60,97(15,93)$ & $<0,001^{*}$ \\
Rentang & $30,76-46,05$ & $40,63-92,04$ & \\
\hline
\end{tabular}

*Analisis menggunakan uji t independen

pada karakteristik neonatus dan maternal tidak berbeda bermakna.

Perbandingan kadar neopterin serum dengan luarannya yang mengalami perbaikan ataupun perburukan seperti yang tercantum pada Tabel 3. Tabel 3 menunjukkan bahwa kadar neopterin pada luaran perburukan lebih tinggi dibanding dengan luaran perbaikan dan disimpulkan bahwa terdapat perbedaan yang bermakna. Kemudian, dari kadar kedua neopterin tersebut dibuat kurva ROC untuk prediksi luaran (Gambar).

Prosedur ROC menunjukkan bahwa luas area di bawah kurva kadar neopterin adalah 98,1\% (95\% IK=0,882-1,000; $\mathrm{p}<0,001$ ) seperti tampak pada Gambar. Kemudian, kadar titik potong kadar neopterin serum $>43,13 \mathrm{ng} / \mathrm{mL}$ dengan sensitivitas $94,1 \%$ dan spesifisitas $96,0 \%$.

\section{Pembahasan}

Pada penelitian ini dari 42 subjek didapatkan 17 subjek masuk kelompok luaran perburukan dan 25 subjek dengan luaran perbaikan. Pada karakteristik maternal didapatkan faktor risiko di antaranya ketuban pecah dini lebih dari 18 jam, ketuban hijau, demam pada ibu, ibu diabetes melitus, polihidramnion, dan ibu hipertensi. Pada karakteristik neonatus didapatkan juga faktor risiko, berdasarkan jenis kelamin didapatkan 26 subjek laki-laki dan 16 subjek perempuan. Pada penelitian ini hampir keseluruhan subjek yang didapatkan melalui persalinan sectio cesarea, 11 subjek pada kelompok perburukan dan 18 subjek pada kelompok luaran perbaikan. Kejadian sepsis awitan dini (24 subjek) ditemukan lebih banyak dibanding dengan awitan lanjut (18 subjek). Kultur positifdidapatkan pada 4 subjek penelitian, dengan kuman yang ditemukan berbeda-beda. Semua faktor risiko yang didapatkan dari faktor maternal dan faktor neonatus yang teridentifikasi tersebut tidak bermakna $(p>0,25)$ sehingga untuk menentukan neopterin sebagai nilai prediktor tidak diikutsertakan.

Pada penelitian ini didapatkan hasil yang bermakna peningkatan kadar neopterin dengan luaran perburukan sepsis neonatorum dengan $\mathrm{p}<0,01$. Kadar neopterin serum rata-rata yang didapatkan pada sepsis luaran perburukan 60,97 $\mathrm{ng} / \mathrm{mL}$ dengan rentang nilai 40,63-92,04 $\mathrm{ng} /$ $\mathrm{mL}$. Peningkatan kadar neopterin yang lebih tinggi pada pasien perburukan disebabkan oleh kerusakan sel-sel endotel yang luas disebabkan oleh proses inflamasi. Produksi neopterin erat kaitannya dengan aktivasi sistem imun seluler, sedangkan biosintesis neopterin dalam keadaan inflamasi itu disebabkan oleh peningkatan kadar interferon gama endogen yang dilepaskan dari sel limfosit T yang diaktifkan..$^{10,11}$

Berdasar atas kurva ROC, kadar AUC neopterin 98,1\% (95\% IK=0,882-1,000; $\mathrm{p}<0,001)$ secara statistik kadar tersebut tergolong sangat baik. Kadar AUC 98,1\% artinya apabila kadar neopterin digunakan untuk memprediksi ada atau tidak perburukan pada sepsis neonatorum terdapat 98 neonatus yang mengalami perburukan. Titik potong yang diperoleh dari proses AUC adalah $>43,13 \mathrm{ng} / \mathrm{mL}$ dengan sensitivitas $94,1 \%$ dan spesifisitas 96,0\%. Hal ini berarti nilai neopterin $>43,13 \mathrm{ng} / \mathrm{mL}$ akan memprediksikan penderita sepsis neonatorum mengalami perburukan.

Hasil penelitian sebelumnya melaporkan juga kadar titik potong. Akan tetapi, kadar titik potong yang hanya sebagai parameter diagnostik adalah $32 \mathrm{ng} / \mathrm{mL}$ yang memiliki sensitivitas $78,9 \%$ dan spesifisitas 95,0\%.5 Penelitian lain melaporkan titik potong yang lebih tinggi kadar neopterin serum untuk mendeteksi sepsis adalah 70,56 ng/ $\mathrm{mL}$ dengan sensitivitas $94,7 \%$ serta spesifisitas $88,6 \%$. $^{7}$ Penelitian tersebut di atas tidak dapat dibanding dengan penelitian ini karena neopterin hanya sebagai parameter diagnosis.

Keterbatasan pada penelitian ini walaupun 
hasil didapatkan baik dan bermakna, tetapi jumlah sampel yang diperiksa sedikit karena keterbatasan biaya dan juga waktu penelitian. Walaupun demikian, dengan jumlah sampel yang optimal kemungkinan ada faktor lain yang ikut serta untuk memprediksi luaran perburukan sepsis neonatorum.

\section{Simpulan}

Kadar titik potong neopterin serum adalah 43,13 $\mathrm{ng} / \mathrm{mL}$ dengan memiliki sensitivitas $94,1 \%$ dan spesifisitas 96,0\%. Biomarker ini dapat menjadi salah satu parameter memprediksi dini luaran perburukan sepsis neonatorum baik awitan dini maupun awitan lanjut dan menentukan terapi lanjutan.

\section{Daftar Pustaka}

1. Shane AL, Stoll BJ. Neonatal sepsis: progress towards improved outcomes. J Infect. 2014;68(Suppl 1):S24-32.

2. Shah BA, Padbury JF. Neonatal sepsis: an old problem with new insights. Virulence. 2014;5(1):170-8.

3. World Health Organization. World Health Statistics 2016: monitoring health for the SDGs. Jeneva: WHO Press; 2016.

4. Haque KN. Understanding and optimizing outcome in neonates with sepsis and septic shock. Dalam: Vincent JL, penyunting.
Yearbook of intensive care and emergency medicine 2007. New York: Springer Science + Business Media Inc.; 2007. hlm. 55-68.

5. Simonsen KA, Anserson-Berry AL, Delair SF, Davies HD. Early-onset neonatal sepsis. Clin Microbiol Rev. 2014;27(1):21-47.

6. Usman A, Sukadi A, Mose JC. Clinical outcome of cytomegalovirus infection on low birth weight infants. GMHC. 2014;2(2):8590.

7. Boseila S, Seoud I, Samy G, El-Gamal H, Ibrahim TS, Ahmed A, dkk. Serum neopterin level in early onset neonatal sepsis. Am J Sci. 2011;7(7):343-52.

8. El Nemer FS, Midan DAR, Mohamed AF. Serum neopterin level in early onset neonatal sepsis. Am J Biosci. 2015;3(3):80-6.

9. Anggara MY, Gurnida DA, Effendi SH. Correlation between neopterin levels in premature infants with sepsis and the signs and symptoms of neonatal sepsis using the Töllner sepsis score. Pteridines. 2014;25(2):49-52.

10. Baydar T, Yuksel O, Sahin TT, Dikmen K, Girgin G, Sipahi H, dkk. Neopterin as a prognostic biomarker in intensive care unit patients. J Crit Care. 2009;24(3):318-21.

11. Tasdelen Fisgin N, Aliyazicioglu Y, Tanyel E, Coban AY, Ulger F, Zivalioglu M, dkk. The value of neopterin and procalcitonin in patients with sepsis. South Med J. 2010;103(3):216-9. 